\title{
Corporate Board Characteristics, Managerial Entrenchment and Diversification Strategy: Evidence from Tunisian Context
}

\author{
Kouki Marouan ${ }^{1}$ \\ ${ }^{1}$ Faculty of Management and Economics Sciences of Tunis, Tunisia \\ Correspondence: Kouki Marouan, Faculty of Management and Economics Sciences of Tunis, Tunisia. E-mail: \\ koukimarouan@yahoo.fr
}

Received: April 28, 2015

Accepted: May 13, 2015

Online Published: June 20, 2015

doi:10.5539/ijbm.v10n7p184

URL: http://dx.doi.org/10.5539/ijbm.v10n7p184

\begin{abstract}
The aim of this paper is to analyze the role of the board of directors and the management entrenchment in the explanation of diversification strategy of the Tunisian firms. In particular we focus on the characteristics of these two opposite directions bodies where the first controls the second in explaining the strategic choices of the firm. We find evidence for the negative effect of the board size and outside directors on the diversification strategy of the firm. The empirical result points also the negative effect of the CEO duality, which is inconsistent with the agency hypothesis.
\end{abstract}

Keywords: board of directors, manager ownership, entrenchment, diversification strategy

\section{Introduction}

The effect of corporate governance on firm diversification strategy has received important attention in the management and finance literature in recent years. This increased subject has been developed by the financial scandals that appeared in early part of this decade. To address the problems caused by recent financial crises, in particular those related to governance system failures, the majority of firms are required to have a board of directors that must meet certain conditions, namely the presence of several directors ,the existence of sub committees and the independence of directors of the management team (Hermalin \& Weisbah, 2003), since it is on the one hand an obligation under the laws and regulations(see the Sarbane-oxley act of 2002) of each country, and also an organizational solution to minimize agency problems that plague business. In this context, most empirical studies that have attempted to emphasize the associations between Ownership structure and firm diversification strategy have been investigated in the Common-law countries and globally consider shareholder power against management behavior. They implicitly suppose convergence of interests between all types of shareholders. Moreover, it cleary accepted that diversification strategies represent a circumstance where agency problems between managers and shareholders are important and represent a forme of manager perquisite (Denis et al., 1999).

According to Jensen (1986), Stulz (1990), La Porta et al. (1999) market imperfections with higher asymmetric information may allow large shareholders and manager to exploit the company for their own wealth. Such agency costs are likely to occur for diversified firms in emerging markets where ownership is more concentrated and investor protection is too low. Jensen and Meckling (1976), Thietart (1992) argue that when ownership and management are separated which reduce the performance and the strategic profit of the firms, the composition, the number and the independence of the board of directors must garantie monitoring mechanisms to reduce all the agency costs. $\mathrm{Li}$ (1994) considers that the differences in corporate governance in many countries appear to be the result of changes in the organizational structure of the company, especially ownership patterns and boards composition. According to Charreaux (2000) the board of directors is considered one of the privileged control mechanism contributing to the goal of creating value, is responsible for protecting the interests of stakeholders in the firm, it must also play various missions in order to align the interests of executives with those of shareholders.

Contrary to Yates (2005), Beiner and Schmid (2005) show that large shareholders and corporate governance mitigate value destroying diversification. Denis et al. $(1997,2002)$ find that managerial ownership is negatively related to the development of diversification strategy. In this context, greater latitude and discretions are given to manager to pursue self-serving interests and own utility at the expense of the principal. These results are also 
confirmed by Jiraporn et al. (2006) in a context of poor protection of the minority shareholders. Bhagat et al. (2006) show that the number and the percentage of stocks owned by directors have an effect on the aptitude of the board to control management. Furthermore, when we examine the association between diversification and corporate governance, it is important to add to this monitoring variable a broader set of governance indicators as board size, CEO duality, institutional investors, the independent directors. Gleason et al. (2012) noted that if the board of directors is well structured, sufficient monitoring and disciplinary actions will take place to impede all the manager's proposals that conduct to entrenchment behavior or personal perquisite consumption.

Although the large number of studies, there is still much debate on the relationship between characteristics of the Board, managerial entrenchment and firm diversification. The purpose of this article is to analyze the role of the board of directors and the executive in explaining the company's diversification strategy. In particular, we focus on the characteristics and behaviors of these two directions bodies which one controls the other in explaining the strategic choices of the company both from theoretical and empirical findings.

The remaider of the paper is organized as follows; section 2 briefly reviews the literature. Section 3 presents the study's data and methodology; section 4 summarizes the empirical findings of the analysis. The conclusion is in the final section.

\section{Literature Review}

According to Shleifer and Vishny (1997), government system must protect investors' wealth from possible expropriation by managers/owners and ensure them an adequate profitability. In this context managers have an incentive to take actions that are not in best interests of the shareholders. Jensen (1986) and Stultz (1990) consider that diversified companies are likely to engage easier in empire building when asymmetric information is higher.

\subsection{Board Characteristics and Diversification}

Fama (1980) argues that the board is one of the fundamental elements of the internal control mechanism to monitor managers and limit agency costs. In this case, it is supposed to play a major role in corporate governance and is responsible for monitoring the strategic choices and prevention of conflicts of interests.

\subsubsection{The Board Size}

The function of the board of directors is to assure that management of the firm is done in accordance with shareholder value maximizing goal and to control managers on important decisions such as diversification. The sarbane-oxley encourages firms to use smaller size of boards which may give better monitoring than large board. In this context, Yermack (1996) shows that supervision of manager's behavior seems to be more effective with smaller board than larger one. However, Coles et al. (2006) do not confirm this result where their study shows that not all firms are well controlled by smaller size of board. The implication of these explanations is an inverse relationship between the size and diversification (Yermack, 1996, Eisenberg et al., 1998; Cornett et al., 2000). Linck et al. (2008) by examining a sample of 7,000 companies, they showed that diversification strategy is better developed for a smaller board of directors. Moreover, Cheng (2008) shows that large boards are associated with low levels of diversification. This result is consistent with the idea that the problems of coordination and communication become more difficult to resolve when the size of board grows.

Inversely, many other studies do not share the same result as obtained before. Thus Pearce and Zahra (1992) showed that a large board has more control over the leader thereby limiting its opportunistic behavior. This same consequence is confirmed by the study done by Dalton et al. (1998), which showed that this positive relationship between board size and firm performance is less obvious for Small and medium-sized enterprises (SMEs). Bhagat and Black (2002), Chen et al. (2005) and Black et al. (2006) do not find a statistically significant relationship between board size and diversification. Through a study on Australian firms, Kiel and Nicholson (2003) find that large boards are not a barrier to good diversification. Moreover, Anderson et al. (2004) find that firms with large board have a low cost of debt. According to Adams and Mehran (2005), factors that influence the association between the board size and diversification are much more related to the control of the manager and to the quality of decision-making. Consequently, a larger board provides more resources for businesses and, therefore and improve diversification for the best interests of shareholders.

\subsubsection{Outside Directors}

Since the recent financial crisis and the resulting passage of the sarbane oxley, outside directors of the board become the focal point of corporate governance. According to the SOX, the term independent director means a member of a board of directors who is not affiliated with the top executives and does no have a material or pecuniary relationship with firm. And he is likely to give vigilant oversight over company to control managerial 
opportunisms and support shareholder value.

Perceived as to improve the functioning of the board, independants directors have been defined through two approaches: (i) firstly, according to 'Resource Based View' where the board is seen as an instrument that can help create skills (Charreaux, 2000), outside directors are positioned as experts that have role to bridge the weaknesses of the firm and put their skills to the service of management in order to improve its competitive position. (ii) secondly, according the dependency theory, outside directors can play an active role in the arbitration in case of disagreement between insiders and outsiders and helps to reduce agency problems (Pfeffer \& Salancik, 1978; Cotta, 2001).

Several studies testing the effect of outside directors on diversification, have obtained mixed results. Rosenstein and Wyatt (1990) show that the number of the outside directors meetings affects positively the stock markets. Hossain et al. (2000) also found a positive relationship between higher levels of board independence and corporate diversification. Chung et al. (2003) find that board independence positively affects diversification through the ability of outside directors to provide effective means of control of executive activities. However, Bhagat and Black (2002) found a negative relationship between the proportion of outside directors in the board and the choice of diversification. Prevost et al. (2002) and Connelly and Limpaphayom (2004) do not find a statistically significant relationship between the presence of independent directors and diversification strategy.

\subsection{Managerial Ownership Characteristics and Diversification Strategy}

\subsubsection{Entrenchement Behavior, Manager Ownership and Diversification}

Under traditional agency problems between principal and agent, managers have incentives to take actions that do not maximize the shareholders' welfare (Jensen \& Meckling, 1976; Jensen, 1986). This is clearly recognized by Shleifer and Vishny 1989 where entrenched managers appear to be using their discretions more for personal agendas than corporate wealth. They entrench themselves by specific investment that reduce the risk of their revocation and make themselves valuable to shareholders and costly to replace. Amihud and Lev (1999) and Stulz (1990) also point that through diversification, it is assumed that managers extend firm size, decrease firm risk at the expense of lower stockholders income and developing more personal gains. Accoding to Pigé (1998) entrenchment is analyzed from two points of view: (i) from manager himself, entrenchment concerns all things and behavior that can maintain his job, increase his liberty to decide and obtain private benefits (Charreaux, 1997). (ii) from shareholders, entrenchment is perceived either as detrimental (Jensen, 1993) when it leads to higher costs, non optimal investment, or favorable when it enhances the company' vital relationship to ensure its growth.

According to Jensen (1986), stultz (1990), higher asymmetric information may permit managers to more simply use the firm for own interests. Such option for exploitation is likely to occur when stockholders are less protected. And it is straightforward for diversified companies in emerging markets to be involved in empire building. Lins and Servaes (2002) show that in merging markets minority stockholders are easly to be exploited if manager-owner employ pyramid ownership structures to isolate their cash flow right from control. In such situation entrenched managers are expected to develop a diversified firm like their own personal goal and tend to be over-invested. Jensen and Meckling (1976) consider diversification as an essential aspect when examining the agency problems between managers and shareholders. Rose and Shepard (1997), Aggarwal and Samwick (2003) argue that Diversification strategies are generally as poor governance device because they offer to managers the option to be entrenched and have more private benefit. Denis et al. (1997) have found a negative relationship between managerial ownership and diversification. In other words, the existence of a managerial stock holdings or control block is negatively related to the implementation of diversification strategies. Directors have greater freedom to pursue strategies that are not always consistent with the objective of maximizing shareholder wealth. These results are confirmed by more recent study by Denis et al. (2002) on international diversification. This relationship also exists in the case where the protection of shareholders' interests is low (Jiraporn et al., 2006).

Krivogorsky (2006) has found a positive relationship between managerial ownership and business diversification. However, this relationship remains insignificant. Cornett et al. (2008) has showed a significant positive association between managerial ownership and diversification. On the other hand, if managers hold equity interests, it becomes more difficult for owners outside to exercise control. This effect of entrenchment is particularly significant for an important managerial ownership. In this case, managers will not have as their primary objective the maximization of corporate value, a negative relationship between managerial ownership and business diversification is possible. 


\subsubsection{The CEO Duality and Diversification}

When the CEO is also the chairman, the ability of the board to monitor the CEO is lower (Jensen, 1993). Gul and Leung (2004) suggest that business leaders who also serve as a chairman of the board could reduce the board's ability to exercise effective control over the management and thus negatively affect the strategic choices. Brickley et al. (1997) confirm that there are also agency costs coupled with having two persons holding the titles of chairman and CEO. They find no evidence for companies with separate occupations have better outcomes than those who have the same person holding both the two functions. However, Pi and Timme (1993) find that firms with a person having both functions are less effective than those with two people occupying the two functions. Krivogrsky (2006) and Cornett et al. (2008) distinguish a negative relationship between the Chief Executive duality and business diversification. Furthermore, Pigé (1998) notes that the level of entrenchment is defined by the unexplained part of the annual preservation decision (or replacement) by the Board of Directors, after taking into account the performance of the year and the age of the manager.

Hoskisso and Hitt (1990) argue that the most important point to note however is consider diversification is developed no only because of the strategic goal of the firm but also for the entrenched managers who have private incentives from diversification. This is clearly recognized by the position of managers relative to stockholders, have an incentive to be over-invested in the firms. Wang and Barney(2006) argue that managers are likely to have more reputation, and private benefits. Therefore CEOs might become enough sufficient to easily reduce the risk of their dismissal. It follows, that managers are likely to support measures that facilitate more safe income. Eisemmann (2002) shows that companies with managers that have lower share ownership are more diversified than do owner-managed companies. Eisenhardt (1989) show that CEO duality increase asymmetric information between manager and the board which accentuate agency problems between insiders and outsiders. Boyd et al (2005) note that CEO duality tears the equilibrium power between CEO and the board which reduce the board's controlling efficiency. Kim et al. (2009) show that in the case of unrelated industries, CEO duality and corporate diversification are associated positively. They recognized that this relationship is less pronounced when we consider the effect of corporate governance mechanisms.

\section{Data and Methodology}

\subsection{Sample Description}

The sample of the study includes 30 Tunisian companies listed on the Stock Exchange of Securities Tunis (TSE), observed over a period of 15 years (1997-2011) allowing us to constitute a cylinder of panel date of 450 observations.

\subsection{Measurement of Variables and Hypothesis Development}

\subsubsection{The dependent Variable: The Diversification Strategy}

To assess the degree of diversification of a firm among its various activities, previous research has suggested two possible approaches: (i) using Rumelt's (1974) corporate strategy typology based on the links between diversification strategy (single, dominant, related and unrelated business), administrative structure and performance. (ii) using measures based on indices such as the Herfindahl index and entropy index. According Batsh (1993), the two measures are frequently significant in analyse the diversification strategies.

(i) Diversification Herfindahl (DivHerf): This measure uses the Herfindahl concentration index to measure diversification.

$$
\text { DivHerf }=1-H
$$

Where $H=\sum_{i=1}^{n} P_{i}^{2}$ and Pi measures the proportion of the turnover of the business (xi) to income ratio in the industry. $\mathrm{Pi}=\mathrm{xi} / \mathrm{X}, \mathrm{n}$ is the number of the company's activities. Herfindahl diversification appears to be the complement of the concentration of the company's operations, meaning by this measure that the total of diversification and concentration must be equal to unity. Several authors have used this method, we can refer to the studies done by Lang and Stulz (1994), How and Jarell (1995), Denis et al (1994).

$$
\text { DivHerf }=1-\sum_{i=1}^{n}\left(x_{i} / X\right)^{2}
$$

(ii) Diversification entropy (Entropy): this measure is proposed by several authors: Jacquemin and Berry, Chatterjee and Blocher (1992), Palepu (1985). 


$$
\text { Entropie }=\sum_{i=1}^{n} P_{i} \log \frac{1}{P_{i}}
$$

Where Pi represents the share in the company's turnover in the ith industry. This index is zero when the company operates in one industry and takes $\log n$ value when the total income is returned in a fair manner between $n$ industries in which it operates. The advantage of such a measure is its decomposition property of the value of the index types of components corresponding to different levels of activity.

\subsubsection{The Explanatory Variables}

The characteristics of the Board: we use two variables to describe the charecteristics of the board: the size of the board and the outside directors.

-The board size (BSize): Jensen and Meckling (1976), Fama (1980) define the board function as to monitor and encourage managers to create value for shareholders. According to Faleye. (2004), a board is simply a group of people working together to accomplish a common goal. Hence, its success depends on the dynamics of the group and their interaction. In practice, the size of the board may vary significantly from one company to another, within the limit provided by law (Charreaux \& Pitol-Belin, 1987). Therefore, the board size may be a lever used by companies and it is likely to influence the effective functioning of the management. Therefore, The size of the board is a very important feature which can have an impact on this dynamic. By analyzing the impact of the board size on the company's diversification measures, Yermack (1996) has shown that there is a significant negative relationship.Other studies have previously shown that this relationship is positive. Indeed, when the board size increase, the coordination and decisions will be less effective which gives the opportunity to the leader to develop diversification in accordance with his utility function (shaw 1981, Jewell \& Reitz, 1981, Gladstei, 1984; Olson, 1982). We measure the board size by the total number of directors in the board.

H1: The board size has a positive impact on the diversification strategy.

-The Independent board Directors (BIND): An outside director must not have significant contractual relationships with the company, he is supposed to play a more important role than an internal administrator in the control of managers since he is not a shareholder or former official in the company. According to Fama (1980), an outside directors are considered to be a professional arbitrator whose main task is to stimulate and control competition among the senior executives of the company. Thus, they are more effective than inside directors in the control and discipline of the manager (Rosenstein \& Wyatt, 1990; Byrd \& Hickman, 1992). Indeed, Godard and Schatt (2004) put forward the idea that outside directors have an important role in the effectiveness of the diversification strategy in line with shareholders' wealth. This variable is measured by the proportion of the outide directors in the board.

\section{H2: The presence of outside directors has a negative effect on business diversification.}

The Entrenchment behavior: we consider three proxies to measure the management entrenchment: (1) the CEO duality, (2) the Manager ownership (3) the risk of over-investment.

-The CEO Duality (DUAL): this variable constitutes an indicator of the power structure in the Board of Directors when the manager takes the same time as Chairman of the Board. Fama and Jensen (1983) and Jarrell et al. (1988) suggested that the duality is negatively related to the firm's diversification strategy. Sridharan and Marsinko (1997), demonstrated that duality reduces the independence of the board and results in more agency costs due to conflicts between the board and the manager. Boyd (1994), demonstrated that duality actually translates into business performance loss for less diversified firms. Christine Panasian (2004) suggests that duality is not a significant factor in explaining the firm's diversification strategy. We measure this variable as equal to 1 if the function of the Chief Executive Officer and Chairman of the Board are united in one person, 0 otherwise.

\section{H3: The CEO duality has a negative impact on business diversification.}

-Management ownership (MOW): The increase in managerial ownership should be a positive signal to the diversification of the firm because the higher the stake held by the leaders, the lower the difference of interests between shareholders and managers will be. However, several studies have found that when management ownership is higher, firms ar less diversified. According Morck, Shleifer, and Vishny (1988), Jensen and Ruback (1983), the relationship between the CEO ownership and firm diversification strategy is non linear and is inclined to be more negative. We measure this variable as a dummy variable taking the value of 1 if the manager holds shares in the company and the value 0 otherwise. 
H4: we anticipate a positive relationship between management ownership and diversification.

-The risk of overinvestment (OINV): overinvestment is a situation in which managers will squander free cash flow by investing in too many projects especially negative NPV projects rather than pay out cash to shareholders. Jensen (1986) considers a situation of over-investment when the company has FCF (Free Cash Flow positive) while its future growth opportunities are poor (tobin's $Q$ is less than 1). In this case we use a dummy variable that takes the value 1 when the risk of over-investment is higher and the value 0 when the risk is low. The earlier financial studies suppose positive relationship between the risk of over-investment and diversification strategy. According to Shleifer and Vishny (1989), Mork et al. (1990) and Paquerot (1997) this positive effect is due to the entrenchment hypothesis. For Castanias and Helfat (1992), managerial rents are produced through leadership abilities. Hirschleifer (1993), Garvey and Swann (1994) and Charreaux and Desbrières (1997) show that entrenchment does not mean inefficiency of investment. We measure this variable as follows: OINV takes the value 1 if and only if Tobin's $\mathrm{Q}<1$ (non-existence of growth opportunities) and Free Cash Flow $>0$. And 0 otherwise.

H5: we assume a positive relationship between the risk of over-investment and diversification strategy

Control variables: in the table 1, we consider four control variables that may explain the company's diversification strategy: profitability, Free cash flow, Growth and the firm size.

Table 1. Characteristics of the firm and measures of the control variables

\begin{tabular}{lll}
\hline & Abbreviation & Measure of variable \\
\hline $\begin{array}{l}\text { Profitability } \\
\text { Free Cash Flow }\end{array}$ & PROF & The profitability of the capital - interest rate. \\
Growth rate of the assets & GRF & $\begin{array}{l}\text { Operating profit }+ \text { depreciation allowance }- \text { investment expenditure (Jensen 1986) } \\
\left(\mathrm{TA}_{\mathrm{t}}-\mathrm{TA}_{\mathrm{t}-\mathrm{l}}\right) / \mathrm{TA}_{\mathrm{t}-1} \\
\text { Where } \mathrm{TA} \text { is total assets }\end{array}$ \\
Size of the company & SIZE & Natural Logarithm of total asset \\
\hline
\end{tabular}

\subsection{The Model to Be Tested}

In order to test the relationship between board carecteristics, management entrenchment and diversification strategy, we propose two econometric models as follows:

Model 1: Diversification $n_{i t}=\alpha_{0}+\alpha_{1} B O A R D_{i t}+\alpha_{2} C V_{i t}+\varepsilon_{i t}$

Model 2: Diversification $n_{i t}=\lambda_{0}+\lambda_{1}$ Entrenchment $t_{i t}+\lambda_{2} C V_{i t}+v_{i t}$

The first model examines the relationship between diversification and Board characteristics as measured by Board size (BSIZE) and outside directors (BIND). And second model analyzes the effect of management behavior as measured by entrenchment variables (DUAL, MOW, OINV) on firm diversification strategy. Where diversification is measured by DivHERF and Entropie and CV is control variables as measured by profitability (prof), Free cash flow (FCF), Growth (Growth) and the firm size (SIZE).

\section{Empirical Tests}

\subsection{Descriptive Statistics}

Table 2 shows that our sample has an average board size of 10 with a maximum value of 14 and a minimum value of 6 . In fact, the researchers do not seem to agree on the number of directors who is working to ensure proper functioning of the Board. Indeed, Lipton and Lorsch (1992) suggest that large boards may be less effective than those of small size. They advocate a board between 8 and 9 directors. The idea is that when boards have a tendency to be large, agency problems increase and the board becomes less independent to exercice efficient monitoring. In addition, the board's members will have more difficulty to convey their attitude given the limited time given to them at meetings. According to Jensen (1993), boards composed of more than 7 or 8 directors are ineffective and become more easily controlled by the executive. Indeed, the larger the size of the board, the less coordination, communication and decision-making will be effective. Kiel and Nicholson (2003), believe that eight directors would be the maximum and 6.6 the common range of the board. Brown and Caylor (2004) show that firms with size between 6 and 15 have a greater return on equity and profit margins higher than other companies. While, Leblanc and Gillies (2004) find that a size of between 8 and 11 administrators would be optimal.

In addition, the percentage of outside directors is equal on average to $50 \%$. This rather high proportion proves 
that listed Tunisian firms are dominated by outside directors because of the important role of the latter in corporate governance. Because they can control the strategies of leaders and ensure that they apply the norms and standards rules and restrict their abusive power, so that they do not engage in activities that are against the interests of shareholders and affecting negatively business performance. Our result is consistent with that found by Adams and Mehran (2005). These authors found that $69 \%$ of the board are outside directors.

Table 2. Statistics descriptive of the quantitative variables

\begin{tabular}{lcccccc}
\hline & BSIZE & BIND & PROF & FCF & GROWTH & SIZE \\
\hline Mean & 10.01778 & 0.494618 & 0.002911 & 0.081245 & 105031.0 & 8.194874 \\
Median & 10.00000 & 0.558442 & -0.009305 & 0.058097 & 0.045539 & 7.913125 \\
Maximum & 14.00000 & 1.000000 & 0.282569 & 0.301050 & 47263856 & 9.790359 \\
Minimum & 6.000000 & 0.000000 & -0.253198 & -0.098779 & -1.000000 & 0.000000 \\
Std. Dev. & 1.718404 & 0.238893 & 0.058443 & 0.075241 & 2228040. & 0.827026 \\
Skewness & -0.842206 & -0.028296 & 0.519368 & 0.647556 & 21.14243 & -1.688710 \\
Kurtosis & 4.720353 & 2.310463 & 5.004336 & 2.458021 & 448.0022 & 22.76051 \\
Jarque-Bera & 108.6911 & 8.974944 & 95.55632 & 36.95726 & 3746531. & 7535.339 \\
Probability & 0.000000 & 0.011249 & 0.000000 & 0.000000 & 0.000000 & 0.000000 \\
Observations & 450 & 450 & 450 & 450 & 450 & 450 \\
Cross sections & 30 & 30 & 30 & 30 & 30 & 30 \\
\hline
\end{tabular}

Table 3 describes the qualitative variable as measured by dummy measures $(1$ or 0$)$. Theses variable are CEO duality, Management ownership, and Overinvestment. It is found that $54 \%$ of firms adopt combine the functions of Chairman and CEO and $52 \%$ of companies are managed by the owners. To characterize the risk of overinvestment $30 \%$ of our sample has firms with non optimal investment associated with wastful use of free cash flows.

Table 3. Statistics descriptive of the qualitative variables

\begin{tabular}{lllll}
\hline & Proportion & Std. Err. & \multicolumn{2}{c}{$\begin{array}{l}\text { Binomial Wald } \\
{[\mathbf{9 5 \%} \text { Conf. Interval] }}\end{array}$} \\
\hline DUAL & 0.46 & 0.0235208 & 0.4137754 & 0.5062246 \\
$\mathbf{0}$ & 0.54 & 0.0235208 & 0.4937754 & 0.5862246 \\
$\mathbf{1}$ & & & & \\
MOW & 0.4733333 & 0.0235629 & 0.4270261 & 0.5196405 \\
$\mathbf{0}$ & 0.5266667 & 0.0235629 & 0.4803595 & 0.5729739 \\
$\mathbf{1}$ & & & & \\
OINV & 0.711111 & 0.02139 & 0.6690741 & 0.7531481 \\
$\mathbf{0}$ & 0.2888889 & 0.02139 & 0.2468519 & 0.3309259 \\
$\mathbf{1}$ & & & & \\
\hline
\end{tabular}

\subsection{Estimated Results and Discussion}

Test 1: impact of the board characteristics on the corporate diversification strategy.

The empirical results of the model 1 , show that board size has significantly negative effect on diversification as measured by DIVHERF and confirms the work of Jensen (1993), Hermalin et al. (2003), Yermack (1996). Dalton et al. (1998), Wintoki (2007), showed the existence of a negative relationship between Board size and the choice of diversification strategy. On the other hand, our results show also a significantly positive relationship with ENTROPIE measure, which confirms our basic hypothesis (H1), and with those of Adams and Mehran (2005) considering that Board size has a positive impact on the strategic choices of the firm.

Regarding the independence of the board, the empirical test shows that the percentage of outside directors (BIND) are associated negatively diversification as measured by ENTROPIE and DIVHERF, which support our hypothesis $(\mathrm{H} 2)$ where the presence of these directors allows increase actions of monitoring and control and therefore limits the possibility of diversification accompanied by a discretionary behavior of the leader. 
Table 4. Estimation of the impact of the board of directorson on diversification strategy

\begin{tabular}{|c|c|c|c|c|}
\hline & \multicolumn{2}{|c|}{ DIVHERF } & \multicolumn{2}{|r|}{ ENTROPIE } \\
\hline & Regression 1 & Regression 2 & Regression 3 & Regression 4 \\
\hline $\mathrm{C}$ & 1.351557 & $1.557658^{\mathrm{a}}$ & $0.132229^{c}$ & -0.161426 \\
\hline BSIZE & -0.025596 & $-0.021931^{a}$ & $0.023081^{\mathrm{a}}$ & $0.027490^{\mathrm{a}}$ \\
\hline BIND & -0.408377 & $-0.396719^{a}$ & -0.059585 & $-0.141448^{\mathrm{a}}$ \\
\hline PROF & & $0.485971^{\mathrm{c}}$ & & $-0.849362^{\mathrm{a}}$ \\
\hline FCF & & $-0.520864^{c}$ & & $1.594406^{\mathrm{a}}$ \\
\hline GROWTH & & $3.58 \mathrm{E}-09$ & & $-5.76 \mathrm{E}-09$ \\
\hline SIZE & & -0.025389 & & 0.019954 \\
\hline Ajusted $R^{2}$ & 0.175191 & 0.188645 & 0.025825 & 0.140738 \\
\hline
\end{tabular}

Concerning the control variables we note that the firm size (SIZE) has a negative and insignificant sign, which is not confirmed by the results found by Boyd and Runkle (1993); Pinteris (2002); Adams and Mehran (2005), supporting the idea that diversification is positively associated with the size of the firm. Regarding the variable (FCF), it has the greatest contribution with a high and significant coefficient of 1.594406 proving its explanatory power on the diversification strategy, but also significantly negative with DIVHERF measure.

Test 2: Impact of entrechment behavior of the company's diversification strategy.

We note that duality (DUAL) has a negative and statistically significant impact on diversification confirming the findings of Panasian et al. (2004) and Boyd (1994), who found that this form of ownership has negative effects on the diversification process. In addition, this variable is positively but not significantly related to diversification as measured by ENTROPIE with a coefficient of (0.011003) which explains its weak influence on diversification and corroborating our hypothesis $\mathrm{H} 3$.

Table 5. Estimation of the impact of the entrenchment on diversification strategy

\begin{tabular}{lllll}
\hline & DIVHERF & \multicolumn{3}{c}{ ENTROPIE } \\
& Regression 1 & Regression 2 & Regression 3 & Regression 4 \\
\hline C & $\mathbf{0 . 9 3 2 7 1 1 ~}^{\mathbf{a}}$ & $\mathbf{1 . 4 4 7 3 9 6}^{\mathbf{a}}$ & $\mathbf{0 . 3 3 8 8 3 3}^{\mathbf{a}}$ & -0.151375 \\
DUAL & $\mathbf{- 0 . 2 0 5 5 7 2}^{\mathbf{b}}$ & $\mathbf{- 0 . 1 7 8 7 3 8}^{\mathbf{b}}$ & 0.006497 & 0.011003 \\
MOW & 0.120780 & 0.091338 & -0.015161 & -0.020423 \\
OINV & 0.027117 & 0.025570 & -0.001314 & -0.001543 \\
PROF & & $\mathbf{0 . 4 9 1 0 0 5}^{\mathbf{b}}$ & & $\mathbf{- 0 . 7 8 3 0 2 4}^{\mathbf{a}}$ \\
FCF & & $\mathbf{- . 8 7 7 0 3 8}^{\mathbf{a}}$ & & $\mathbf{1 . 5 0 3 9 2 8}^{\mathbf{a}}$ \\
GROWTH & & $4.62 \mathrm{E}-09$ & & $-5.54 \mathrm{E}-09$ \\
SIZE & & $\mathbf{- . 0 5 4 1 6 6}^{\mathbf{a}}$ & & $\mathbf{0 . 0 4 5 3 0 7}^{\mathbf{a}}$ \\
Ajusted R & & 0.072159 & 0.000317 & 0.102789 \\
\hline
\end{tabular}

We also note that the management ownership (MOW) and overinvestment (OINV) are not significant in the above models where their effects on diversification as measured by ENTROPY are negative. These results, invalidates our hypotheses H4 and H5 and confirm the study conducted by Morck et al. (1988), Jensen and Ruback (1983) who find that the participation of the leader is negatively related with the strategic choice of the company.

\section{Concluding Remarks}

Few studies have investigated the relationship between diversification and the problem of agency costs of equity via the control mechanisms and management entrenchment. Models of the agency typically involve managers and shareholders to have divergent interests and, therefore, less monitoring allowing managers to pursue business strategies at the expense of the shareholders wealth. Several studies suggest that CEO can continue to reduce the business risk by diversification in order to decrease the probability of his dismissal when things will get worse although this strategy is to contradict shareholders' value. Specifically, Amihud and Lev advance the idea that shareholders can reduce investment risk by diversifying; they are less concerned about the enterprise-specific risk. 
The results of our empirical tests have shown that the Board size negatively affects the diversification ratio of a firm. Regarding the outside directors are associated also negatively to diversification ratio which supports our hypothesis that the presence of these directors can increase control actions and monitoring and therefore limits the possibility of diversification accompanied by a discretionary behavior. Concerning the impact of entrenchment behavior on the company's diversification strategy, we observe that the CEO duality has only a negative and statistically substantial effect on the strategic choice of the firm. The others proxies of entrenchment behavior (manager ownership, and the risk of overinvestment) are not statistically significant.

\section{References}

Adams, R., \& Mehran, H. (2005). Corporate performance, board structure and its determinants in the banking industry. Working Paper. Federal Reserve Bank of New York.

Aggarwal, R. K., \& Samwick, A. A. (2003). Performance incentives within firms: The effect of managerial responsibility. Journal of Finance, 58(4), 1613-1650. http://dx.doi.org/10.1111/1540-6261.00579

Amihud, Y., \& Lev, B. (1999). Does the corporate ownership structure affect its strategy towards diversification? $\begin{array}{llrr}\text { Strategic Management } & \text { Journal, } & \text { 20(11), } & 1063-1069\end{array}$ http://dx.doi.org/10.1002/(SICI)1097-0266(199911)20:11<1063::AID-SMJ69>3.0.CO;2-S

Anderson, R. C., \& Reeb, D. M. (2003). Founding-family ownership, corporate diversification, and firm leverage. Journal of Law and Economics, 46, 653-684. http://dx.doi.org/10.1086/377115

Beiner, S., \& Schmid, M. M. (2005). Agency conflicts, corporate governance, and corporate diversification-Evidence from Switzerland. Unpublished manuscript, New York University.

Bhagat, S., \& Black, B. (2002). The non-correlation between board independence and long term firm performance. Journal of Corporation Law, 27, 231-274.

Bhagat, S., Carey, D., \& Elson, C. (2006). Director ownership, corporate performance, and management turnover, Working paper.University of Maryland.

Boyd, B. K. (1994). Board control and CEO compensation. Strateg Manage J., 15(5), 335-344. http://dx.doi.org/10.1002/smj.4250150502

Boyd, B. K., Gove, S., \& Hitt, M. A. (2005). Consequences of measurement problems in strategic management research: the case of Amihud and Lev. Strateg Manage J., 26(4), 367-375. http://dx.doi.org/10.1002/smj.445

Boyd, J. H., \& David, R. (1993). Size and performance of banking firms. Journal of Monetary Economics, 31, 47-67.

Brickley, J. A., Coles, J. L., \& Jarrell, G. (1997). Leadership structure: Separating the CEO and chairman of the board. Journal of Corporate Finance, 3, 189-220. http://dx.doi.org/10.1016/S0929-1199(96)00013-2

Brown, L. D., \& Caylor, M. L. (2004). Corporate governance and firm performance. Georgia State University.

Byrd, J., \& Hickman, K. (1992). Do outside directors monitor managers? Evidence from tender offer bids. Journal of Financial Economics, 32, 195-222.

Castanias R. P., \& Helfat, C. E. (1992). Managerial and Windfall Rents in the Market for Corporate Control. Journal of Economic Behavior and Organisation, 18, 153-184.

Charreaux, G. (1997). Le gouvernement des Entreprises: Coporate Governance.

Charreaux, G. (2000). Le conseil d'administration dans les théories de la gouvernance. La Revue du Financier, 127, 6-17.

Chen, S. S., \& Kim, W. H. (2000). Corporate diversification, ownership structure, and firm value The Singapore evidence. IRFA, International Review of Financial Analysis, 9, 315-326.

Chung, K., Wright, P., \& Kedia, B. (2003). Corporate governance and market valuation of capital and R\&D $\begin{array}{lllll}\text { investments. } & \text { Review }\end{array}$ http://dx.doi.org/10.1016/S1058-3300(02)00063-0

Coles, J. L., Daniel, N. D., \& Naveen, L. (2006). Boards: Does one size fit all? Journal of Financial Economics 87, 329-356.

Comment, R., \& Jarrell, G. A. (1995). Corporate focus and stock returns. Journal of Financial Economics, 37, 67-87. http://dx.doi.org/10.1016/0304-405X(94)00777-X 
Connelly, J. T., \& Limpaphayom, P. (2004). Environmental reporting and firm performance: Evidence from $\begin{array}{lllll}\text { thailand. The Journal of Corporate Citizenship, 13, } & \text { 137-149. }\end{array}$ http://dx.doi.org/10.9774/GLEAF.4700.2004.sp.000015

Cornett, M. M., Marcus, A. J., \& Tehranian, H. (2008). Corporate governance and pay-for-performance: the impact of earnings management. Journal of Financial Economics, 87, 357-373. http://dx.doi.org/10.1016/j.jfineco.2007.03.003

Cornett, M., Hovakimian, G., Palia, D., \& Tehranian, H. (2003). The Impact of the Manager-Shareholder Conflict on Acquiring Bank Returns. Journal of Banking and Finance, 27, 103-131. http://dx.doi.org/10.1016/s0378-4266(01)00210-2

Dalton, D. R., Daily, C. M., Ellstrand, A. E., \& Johnson, J. L. (1998). Meta-analytic reviews of board composition, leadership structure and financial performance. Strateg Manage J., 19(3), 269-290. http://dx.doi.org/10.1002/(SICI)1097-0266(199803)19:3<269::AID-SMJ950>3.0.CO;2-K

Denis, D. J., Denis, D. K., \& Sarin, A. (1997). Agency Problems, Equity Ownership, and Corporate Diversification. Journal of Finance, 52(1), 135-160.

Denis, D., Denis, D., \& Sarin, A. (1999). Agency theory and the influence of equity ownership structure on corporate diversification strategies. Strategic Management Journal, 20, 1071-1076. http://dx.doi.org/10.1002/(SICI)1097-0266(199911)20:11<1071::AID-SMJ70>3.0.CO;2-G

Denis, D., Denis, D., \& Yost, K. (2002). Global diversification, industrial diversification, and firm value. Journal of Finance, 57, 1951-1979. http://dx.doi.org/10.1111/0022-1082.00485

Eisenberg, T., Sundgren, S., \& Wells, M. T. (1998). Larger board size and decreasing firm value in small firms. Journal of Financial Economics, 48, 35-54.

Eisenhardt, K. M. (1989). Making fast strategic decisions in high-velocity environments. Acad Manage J., 32(3), 543-576. http://dx.doi.org/10.2307/256434

Eisenmann, T. R. (2002). The effects of CEO equity ownership and firm diversification on risk taking. Strateg Manage J., 23(6), 513-534. http://dx.doi.org/10.1002/smj.236

Fama, E. F. (1980). Agency problems and the theory of the firm. Journal of Political Economy, 88, 288-307.

Fama, E., \& Jensen, M. (1983). Separation of ownership and control. Journal of Law and Economics, 26, 301-325. http://dx.doi.org/10.1086/467037

Garvey, G., \& Swan, P. (1994). The Economics of Corporate Governance: Beyond the Marshallian Firm. Journal of Corporate Finance, 1, 139-174. http://dx.doi.org/10.1016/0929-1199(94)90001-9

Gladstein, D. G. (1984). Groups in Context: A Model of Task Group Effectiveness. Administrative Science Quarterly, 29, 499-517.

Gleason, K. C., Kim, I., Kim, Y. H., \& Kim, Y. S. (2012). Corporate governance and diversification. Asia-Pacific Journal of Financial Studies, 41, 1-31.

Godard, L., \& Schatt, A. (2004). Caractéristiques et fonctionnement des conseils d'administration français: Un état des lieux. XXVème Congrès de l'AFC Orléans.

Gul, F., \& Leung, S. (2004). Board leadership, outside directors expertise and voluntary corporate disclosures. Journal of Accounting and Public Policy, 23, 351-379.

Hermalin, B. E., \& Michael, S. W. (2003). Boards of Directors as an Endogenously Determined Institution: A Survey of the Economic Literature. Federal Reserve Bank of New York Economic Policy Review, 9(1), 7-26.

Hoskisson, R. E., \& Hitt, M. A. (1990). Antecedents and performance outcomes of diversification: A review and critique of theoretical perspectives. J. Manage, 16(2), 461-509. http://dx.doi.org/10.1177/014920639001600210

Hossain, M., Cahan, S. F., \& Adams, M. B. (2000). The investment opportunity set and the voluntary use of outside directors: New Zealand evidence. Accounting and Business Research, 30(4), 263-273. http://dx.doi.org/10.1080/00014788.2000.9728944

Jarrell, G. A., James, A. B., \& Jeffrey, M. N. (1988). The Market for Corporate Control: The Empirical Evidence Since 1980. Journal of Economic Perspectives, 2(1), 49-68. http://dx.doi.org/10.1257/jep.2.1.49

Jensen, M. C. (1986). Agency costs of free cash flow, corporate finance, and takeovers. American Economic 
Review, 76, 323-329.

Jensen, M. C. (1993). The modem industrial revolution, exit, and the failure of internal control system. Journal of Finance, 48, 831-880. http://dx.doi.org/10.1111/j.1540-6261.1993.tb04022.x

Jensen, M. C., \& Meckling, W. H. (1976). Theory of the firm: Managerial behaviour, agency cost and ownership structure. Journal of Financial Economics, 3, 305-360. http://dx.doi.org/10.1016/0304-405X(76)90026-X

Jensen, M. C., \& Ruback, R. S. (1983). The market for corporate control: The scientific evidence. Journal of Financial Economics, 11, 5-50.

Jewell, L. N., \& Reitz, H. J. (1981). Group Effectiveness in Organizations. Scott-Foresman

Jiraporn, P., \& Ning, Y. (2006). 'Dividend policy, shareholder rights, and corporate governance. Journal of Applied Finance, 16, 24-36.

Jiraporn, P., Kim, Y. S., Davidson, W. N., \& Singh, M. (2006). Corporate Governance, Shareholder Rights and Firm Diversification: An Empirical Analysis. Journal of Banking \& Finance, 30(3), 947-963.

Kiel, G. C., \& Nicholson, G. J. (2003). Board Composition and Corporate Performance: How the Australian Experience informs contrasting Theories of Corporate Governance. Corporate Governance: An International Review, 11(3), 189-205. http://dx.doi.org/10.1111/1467-8683.00318

Kim, K. H., Al-Shammari, H., Kim, B. J., \& Lee, S. H. (2009). CEO duality leadership and corporate diversification behavior. Journal of Business Research, 62(11), 1173-1180.

Krivogorsky, V. (2006). Ownership, board structure, and performance in continental Europe. The International Journal of Accounting, 41(2), 176-197.

La Porta, R., Florencio, L. S., \& Andrei, S. (1999). Corporate ownership around the world. Journal of Finance, 54, 471-517.

Lang, L., \& René, S. (1994). Tobin's q, corporate diversification and firm performance. Journal of Political Economy, 102, 1248-1280. http://dx.doi.org/10.1086/261970

Leblanc, R., \& Gillies, J. (2004). Improving Board Decision-Making: An Inside View. Alternatives Beyond Imagination. Company Directors Conference, Port Douglas, Queensland, AICD

Li, J. (1994). Ownership structure and board composition: A multi-country test of agency theory predictions. Managerial and Decision Economics, 15, 359-368. http://dx.doi.org/10.1002/mde.4090150409

Li, M., \& Wong, Y. (2003). Diversification and economic performance: an empirical assessment of Chinese firms. Asia Pacif. J. Management, 20(2), 243-265.

Linck, J. S., Netter, J. M., \& Yang, T. (2008). The determinants of board structure. Journal of Financial Economics, 87, 308-328. http://dx.doi.org/10.1016/j.jfineco.2007.03.004

Lins K. L., \& Servaes, H. (2002). Is Corporate Diversification Beneficial in Emerging Market? Financial Management, Financial Management Association, 31(2), 5-31.

Lipton, M., \& Lorsch, J. W. (1992). A modest proposal for improved corporate governance. Business Lawyer, 48, 59-77.

Morck, R., Shleifer, A., \& Vishny, R. (1988). Managements ownership and market valuation: An empirical analysis. Journal of Financial Economics, 27, 595-612.

Olson, M. (1982). The Rise and Decline of Nations: Economic Growth, Stagflation and Social Rigidities. Yale University Press.

Panasian, C., Prevost, A. K., \& Bhabra, H. S. (2004). Board Composition and Firm Performance: The Case of the Dey Report and Publicly Listed Canadian Firms.

Paquerot, M. (1997). Stratégies d'enracinement des dirigeants, performance de la firme et structures de contrôle (G. Charreaux ed.).

Pearce, J. A., \& Zahra, S. A. (1992). Board composition from a strategic contingency perspective. Journal of Management Studies, 29, 411-438.

Pfeffer, J., \& Salancik, G. R. (1978). The External Control of Organizations: A Resource Dependence Perspective. New York: Harper \& Row.

Pi, L., \& Timme, S. G. (1993). Corporate Control and Bank Efficiency. Journal of Banking and Finance, 17, 
515-530. http://dx.doi.org/10.1016/0378-4266(93)90050-N

Pige B. (1998). Enracinement des dirigeants et richesse des actionnaires. Finance, Contrôle, Stratégie, 1(3), 131-158.

Pinteris, G. (2002). Ownership structure, board characteristics and performance of Argentine banks. Mimeo: Department of Economics, University of Ilinios.

Prevost, A. K., Rao, R. P., \& Hossain, M. (2002). Determinants of board composition in New Zealand: A simultaneous equations approach. Journal of Empirical Finance, 9(4), 373-397. http://dx.doi.org/10.1016/S0927-5398(02)00002-6

Rose, N. L., \& Shepard, A. (1997). Firm Diversification and CEO Compensation: Managerial Ability or Executive Entrenchment? 28 Rand Journal of Economics, 489-514.

Rosenstein, S., \& Wyatt, J. G. (1990). Outside directors, board independence, and shareholder wealth. Journal of Financial Economics, 26, 175-192. http://dx.doi.org/10.1016/0304-405X(90)90002-H

Rumelt, R. P. (1974). Strategy, structure and economic performance. Cambridge, MA: Harvard University Press.

Shaw M. E. (1981). Group Dynamics: The Psychology of Small Group Behavior. McGrawHill.

Shleifer, A., \& Vishny, R. W. (1989). Management entrenchment: The case of manager-specific investments. Journal of Financial Economics, 25, 123-140. http://dx.doi.org/10.1016/0304-405X(89)90099-8

Shleifer, A., \& Vishny, R. W. (1997). A survey of corporate governance. The Journal of Finance, 52, 737-793. http://dx.doi.org/10.1111/j.1540-6261.1997.tb04820.x

Sridharan, U. V., \& Marsinko, A. (1997). CEO duality in the paper and forest products Industry. Journal of Finance and Strategic Decisions, 10(1), 59-65.

Stulz, R. (1990). Managerial discretion and optimal financing policies. Journal of Financial Economics, 26, 3-27.

THIETART. (1992). Contrôle des dirigeants et pouvoir des gestionnaires: comment assurer l'équilibre? Revue Française de Gestion, 87, 58-62.

Wang, H. C., \& Barney, J. B. (2006). Employee incentives to make firm-specific investments: Implicationsfor resource-based theories of corporate diversification. Acad Manage Rev, 31(2), 466-476. http://dx.doi.org/10.5465/AMR.2006.20208691

Wintoki, M. B., \& Yang, T. (2007). Do firms adjust to a target board structure? Working Paper. University of Georgia.

Yates, L. (2005). What has motivated diversification? Evidence from corporate governance. Unpublished manuscript, University of Maryland.

Yermack, D. (1996). Higher market value of companies with a small board of directors. Journal of Financial Economics, 40, 185-212. http://dx.doi.org/10.1016/0304-405X(95)00844-5

\section{Copyrights}

Copyright for this article is retained by the author(s), with first publication rights granted to the journal.

This is an open-access article distributed under the terms and conditions of the Creative Commons Attribution license (http://creativecommons.org/licenses/by/3.0/). 